\title{
ERRATUM
}

\section{Lymphocyte metallothionein mRNA responds to marginal zinc intake in human volunteers}

\author{
By Adrian K. Allan, Gabrielle M. Hawksworth, Leslie R. Woodhouse, Barbara Sutherland, \\ Janet C. King and John H. Beattie \\ Volume 84 (2000), Number 5
}

\section{Page 751}

For: $\quad$ Fig. 1. Schematic diagram of the procedure for T lymphocyte perparation and reverse transcriptase-polymerase chain reaction (PCR) analysis of metallothionein and $\beta$-actin mRMA. (First column.)

Read: Fig. 1. Schematic diagram of the procedure for T lymphocyte perparation and reverse transcriptase-polymerase chain reaction (PCR) analysis of metallothionein and $\beta$-actin mRMA. (Second column.)
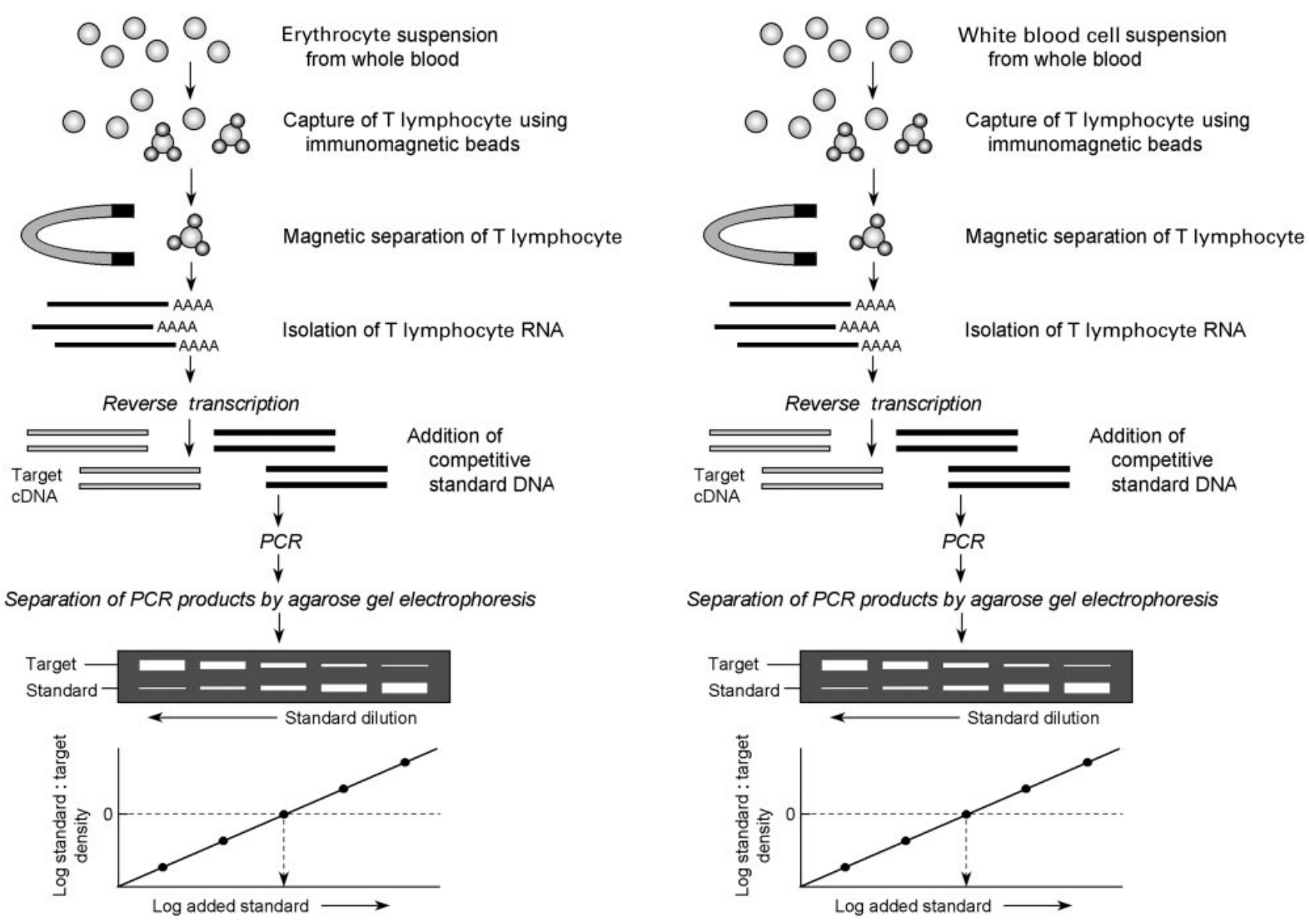